Algal Research

November 2015, Volume 12 Pages 522-528

http://dx.doi.org/10.1016/j.algal.2015.11.002

http://archimer.ifremer.fr/doc/00292/40332/

(c) Published by Elsevier B.V.

\title{
Ultrasound-assisted extraction of R-phycoerythrin from Grateloupia turuturu with and without enzyme addition
} Le Guillard Cecile ${ }^{1,2}$, Dumay Justine ${ }^{2,{ }^{*}}$, Donnay-Moreno Claire ${ }^{1}$, Bruzac Sandrine ${ }^{1}$, Ragon Jean-Yves
, Fleurence Joel ${ }^{2}$, Bergé Jean-Pascal ${ }^{3}$

${ }^{1}$ IFREMER centre de Nantes BP 21105, BIORAFHE, 44311 Nantes cedex 03, France

2 LUNAM Université de Nantes, MMS, Nantes, 2 rue de la Houssinière, BP 92208, 44322, Nantes cedex 03, France

${ }^{3}$ IDMer, 2 rue Batelière, 56100 Lorient, France

*Corresponding author : Justine Dumay, email address : justine.dumay@univ-nantes.fr

cecile.leguillard@wanadoo.fr ; Claire.Donnay.Moreno@ifremer.fr ; Sandrine.Bruzac@ifremer.fr ; Jean.Yves.Ragon@ifremer.fr ; joel.fleurence@univ-nantes.fr ; ipberge@idmer.com

\begin{abstract}
:
The aim of this study was to compare two processes for the extraction of R-phycoerythrin (R-PE) from the red seaweed Grateloupia turuturu: ultrasound-assisted extraction (UAE) and ultrasound-assisted enzymatic hydrolysis (UAEH). Process efficiencies were both evaluated by the yield of R-PE extraction and by the level of liquefaction. Experiments were conducted at 40 and $22^{\circ} \mathrm{C}$, for $6 \mathrm{~h}$, using an enzymatic cocktail and an original ultrasonic flow-through reactor. R-PE appeared very sensitive to temperature, thus $22{ }^{\circ} \mathrm{C}$ is strongly recommended for its extraction by UAEH or UAE. However, the higher processing temperature $\left(40^{\circ} \mathrm{C}\right)$ clearly increased the extraction of water-soluble compounds (up to $91 \%$ of liquefaction).
\end{abstract}

These two new processes are thus promising alternatives for the extraction of water-soluble components including R-PE, from wet seaweeds, with extraction yields at least similar to conventional solid-liquid extraction. 


\section{Graphical abstract}

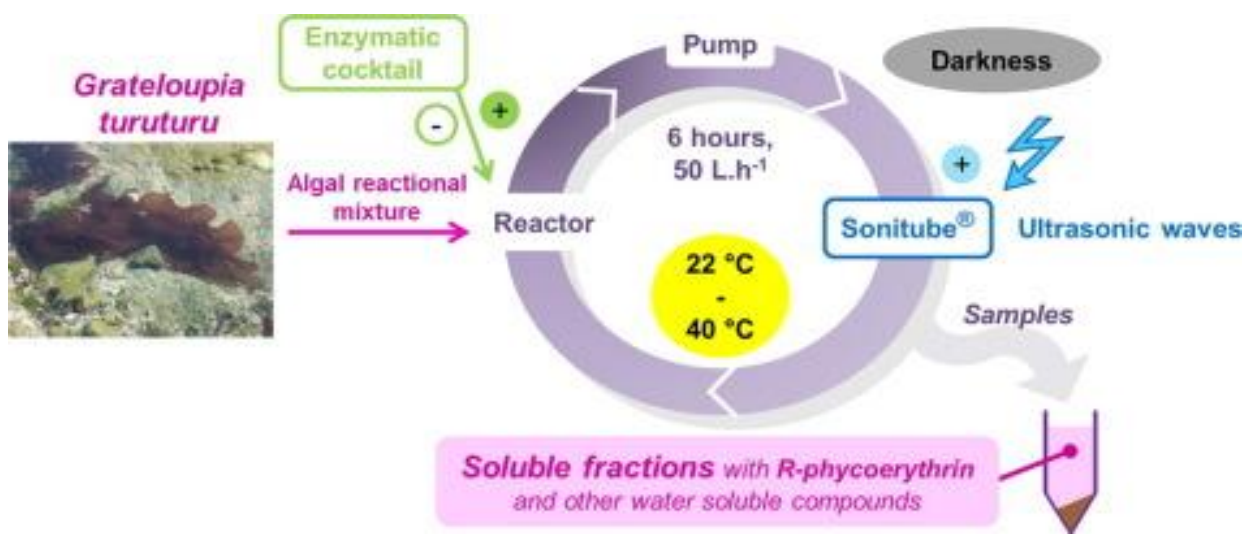

Keywords: Seaweed, Grateloupia turuturu, R-phycoerythrin, Ultrasound-assisted extraction, Ultrasound-assisted enzymatic hydrolysis, Liquefaction 


\section{1. Introduction}

33 The concept of biorefinery continues to make progress with many studies dealing with the

34 development of new technologies for the total recovery of biomass. Among vegetal

35 biomasses, marine substrates like seaweeds are of interest due to their content in a wide range

36 of biomolecules and their worldwide distribution, making them a promising feedstock [1].

37 Although several species have been used for hundreds of years for various applications, many

38 remain underexploited, notably in European countries. Among these, the red seaweed

39 Grateloupia turuturu (Yamada), introduced 45 years ago, is now proliferative and abundant

40 on the French Atlantic coast [2].

41 Red seaweeds are interesting notably for their richness in proteins, polysaccharides and lipids,

42 and also due to some biomolecules such as the valuable R-phycoerythrin (R-PE), a water-

43 soluble pink-purple pigment [3]. R-PE is the main light-harvesting pigment of Rhodophyta

44 and belongs to the phycobiliprotein family [4,5]. In fact, it is the most abundant

45 phycobiliprotein in Grateloupia turuturu, representing up to $0.30 \%$ dw [6]. Such a pigment

46 has a number of potential applications, like as a natural colorant, a fluorescent probe (these 2

47 are already available on the market), an antioxidant, antitumoral and antidiabetic compound

48 [3].

49 The more conventional R-PE extraction method is based on a solid-liquid extraction, in

50 sodium phosphate buffer, from a seaweed powder obtained after freeze-drying and grinding in

51 liquid nitrogen. Such a process is very time-consuming and expensive, making it difficult to

52 upscale, thus extraction alternatives are welcomed. Among these, enzymatic hydrolysis

53 appears promising to extract R-PE [7] as well as other valuable components $[1,8]$. However,

54 regarding the enzymatic extraction of R-PE, despite promising data on Palmaria palmata [7], 
55 no successful results have been obtained on G. turuturu [9]. According to this study, the use of

56 combined polysaccharidases did not improve R-PE extraction, but was useful for the

57 extraction of oligosaccharides [9].

58 In the last decade, the use of ultrasound (US) for extracting natural products from different

59 vegetable biomasses has been validated and increasingly applied. This method is usually

60 named ultrasonic/ultrasound-assisted extraction (UAE), and is already a proven technology

61 for large-scale extraction [10]. However, only very few studies, most of them recent, have

62 been conducted on seaweeds [11-13]. According to Wang et al. [13], the use of US enhanced

63 the extraction efficiency of taurine from the red seaweed Porphyra yezoensis, compared to the

64 conventional solid-liquid procedure. They also noticed that the UAE process required a

65 shorter extraction time and lower operating temperatures, which is interesting regarding the

66 weak stability of R-PE [4]. Ultrasound has already been used to extract phycobilin but from

67 microalgae; Benavides and Rito-Palomares [14] reported that the extraction of B-

68 phycoerythrin was improved by sonication, due to a better disruption of microalgal cells.

69 In recent years, growing number of studies have focused on the simultaneous combination of

70 enzymes and sonication in plants, which was notably developed to enhance the extraction and

71 hydrolysis of polysaccharides [15-18]. It appears that ultrasound irradiation can act as a tool

72 of hydrolysis intensification, sometimes with synergistic effects between the enzymes and US

73 leading to a lower enzyme consumption $[16,17]$. The mechanism of this positive interaction,

74 ultrasound-enzymes, is not well understood, although it could be due to an increase in the

75 mass transfer, through the implosion of cavitation bubbles, enhancing the accessibility of the

76 substrate to the enzyme [16,18]. Moreover, the ultrasound might act by the induction of

77 structural transformations which may affect the active site (secondary structure). The 
78 ultrasound irradiation might confer more stability to the enzyme and they might modify the

79 affinity between the enzyme and the substrate [19].

80 This relatively new process is known as ultrasound/ultrasonic-assisted enzymatic hydrolysis

81 (UAEH) or ultrasound/ultrasonic-assisted enzymatic extraction (UAEE).

82 On seaweeds, a study demonstrated the value of UAEH in speeding up enzymatic hydrolysis

83 (12-fold) [20]. Recently, Korzen et al. [21] highlighted the interest of ultrasound to produce

84 bioethanol from the macroalgae Ulva rigida, using an ultrasound-assisted saccharification and

85 fermentation process. As seaweed cell walls are mainly composed of polysaccharides, such a

86 process could be very helpful in improving access to valuable compounds such as R-PE.

87 To the best of our knowledge, no study has been carried out on the extraction of R-PE under

88 sonication (UAE), or with the simultaneous combination of enzymes and ultrasound (UAEH)

89 on seaweed.

\section{2. Materials and methods}

\section{$91 \quad 2.1$ Materials}

92 Seaweed, G. turuturu, was harvested on $24^{\text {th }}$ May 2013, in the intertidal zone of Batz-sur-Mer

93 on the Atlantic coast, France. Epiphytes were removed by hand and algae were partially

94 dewatered with a spin-dryer, then vacuum-packed (Boulanger INV 40) and immediately

95 frozen. The algae were stored at $-20^{\circ} \mathrm{C}$ in darkness. Four industrial carbohydrases were used

96 and combined according to their similar $\mathrm{pH}$ and temperature optima and their

97 complementarity (Table 1). Regarding our target, all these enzymes do not work at

98 temperatures higher than $40{ }^{\circ} \mathrm{C}$. The enzymatic cocktail was thus composed of Sumizyme TG

99 and Sumizyme MC produced by SHIN NIHON CHEMICAL and kindly provided by Takabio 
100 (Beaucouzé, France); Multifect ${ }^{\circledR}$ CX 15 L kindly provided by DSM; and Ultraflo ${ }^{\circledR}$ XL kindly 101 provided by Novozymes ${ }^{\circledR}$.

102 Table 1. Enzymatic cocktail composition: activities, $\mathrm{pH}$ and temperature ranges. Minimum

103 (Min), maximum (Max) and optimal (Opt) values are given.

\begin{tabular}{|c|c|c|c|c|c|c|c|c|}
\hline & \multicolumn{2}{|c|}{ Activities } & \multicolumn{3}{|c|}{ pH } & \multicolumn{3}{|c|}{ Temperature $\left({ }^{\circ} \mathbf{C}\right)$} \\
\hline & Primary & Secondary & Min & $\operatorname{Max}$ & Opt & Min & $\operatorname{Max}$ & Opt \\
\hline Sumizyme TG & $\begin{array}{c}\text { ß-1,3-glucanase } \\
\text { Botrytis glucanase }\end{array}$ & & 3.5 & 8 & 4 & 40 & 50 & 50 \\
\hline Sumizyme MC & Polygalacturonase & $\begin{array}{l}\text { Protease } \\
\text { Amylase }\end{array}$ & 5 & 6 & 5 & 40 & 45 & 45 \\
\hline Multifect $^{\circledR}$ CX 15L & $\begin{array}{c}\text { Cellulase } \\
ß \text { glucosidase }\end{array}$ & & 4 & 6 & 5 & 35 & 65 & 55 \\
\hline Ultraflo $^{\circledR} \mathbf{X L}$ & $\begin{array}{c}\text { ß glucanase } \\
\text { (endo-1,3(4-)) }\end{array}$ & $\begin{array}{l}\text { Xylanase } \\
\alpha \text { amylase }\end{array}$ & $\mathrm{Nd}^{*}$ & $\mathrm{Nd}^{*}$ & 6 & 40 & 65 & $\mathrm{Nd}^{*}$ \\
\hline
\end{tabular}

* Non-defined values

104

$105 \quad 2.2 \boldsymbol{R}-\boldsymbol{P E}$ temperature stability

106 A portion of the seaweed was freeze-dried and ground in liquid nitrogen to give an algal

107 powder, stored at $-20{ }^{\circ} \mathrm{C}$ in darkness. Following the conventional R-PE extraction method, the

108 resulting powder was suspended in tap water, with a $1 / 20$ ratio $(\mathrm{w} / \mathrm{v})$ for 20 min at $4{ }^{\circ} \mathrm{C}$; then

109 the suspension was centrifuged $\left(25,000 \mathrm{~g}, 20 \mathrm{~min}, 4^{\circ} \mathrm{C}\right)$. The soluble phase, called the water

110 extract, was maintained in darkness at $4{ }^{\circ} \mathrm{C}, 25^{\circ} \mathrm{C}, 30{ }^{\circ} \mathrm{C}$ or $40^{\circ} \mathrm{C}$. The R-PE concentrations

111 ([R-PE]) were monitored over 6 hours. 


\section{$112 \quad 2.3$ Extraction methods}

113 A portion of the seaweed was cut into small pieces (about $5-7 \mathrm{~mm}^{2}$ ) using a cutting mill

114 (Microcut Stephan MC 15). These were subsequently stored at $-20{ }^{\circ} \mathrm{C}$. All the experiments

115 were performed in a jacketed glass reactor vessel $(5 \mathrm{~L})$ containing around $3 \mathrm{~kg}$ of reaction

116 mixture, composed of $20 \%$ wet and cut seaweed homogenized in tap water (corresponding to

117 the minimal water quantity to obtain an effective circulation of the reaction mixture, with the

118 pump, in our conditions) with the $\mathrm{pH}$ adjusted to 5.5 by addition of $6 \mathrm{M} \mathrm{HCl}$ (Radiometer

119 analytical TitraLab $^{\circledR}$ 854). Homogenization was conducted continuously, at $100 \mathrm{rpm}$ (Stuart ${ }^{\circledR}$

120 Overhead Stirrer SS20), and the reaction mixture was circulated using a peristaltic pump

121 (Leroy ${ }^{\circledR}$ Somer) at a flow rate of $50 \mathrm{~L}^{\mathrm{h}} \mathrm{h}^{-1}$. An external circulation system (Hitema ${ }^{\circledR}$ ESE 010

122 and Memmert) was used to control and adjust the temperature $\left(22 \pm 1{ }^{\circ} \mathrm{C}\right.$ or $\left.40 \pm 1{ }^{\circ} \mathrm{C}\right)$ in the

123 reactor during the 6 hours of the process. To ensure R-PE preservation, the whole system was

124 kept in darkness (Figure 1a).

125 Regular sampling $( \pm 30 \mathrm{~mL})$ was carried out throughout the experiment. Samples were

126 immediately centrifuged (15,500 g, $30 \mathrm{~min}, 20^{\circ} \mathrm{C}$, Beckman Coulter Avanti ${ }^{\circledR} \mathrm{J}$-E Centrifuge)

127 providing supernatant and sludge fractions that were weighed and then freeze-dried. The

128 temperature was regulated $\left(22 \pm 1{ }^{\circ} \mathrm{C}\right.$ or $\left.40 \pm 1{ }^{\circ} \mathrm{C}\right)$ and $\mathrm{pH}$ was monitored inside the reactor

129 during the whole experiment. 

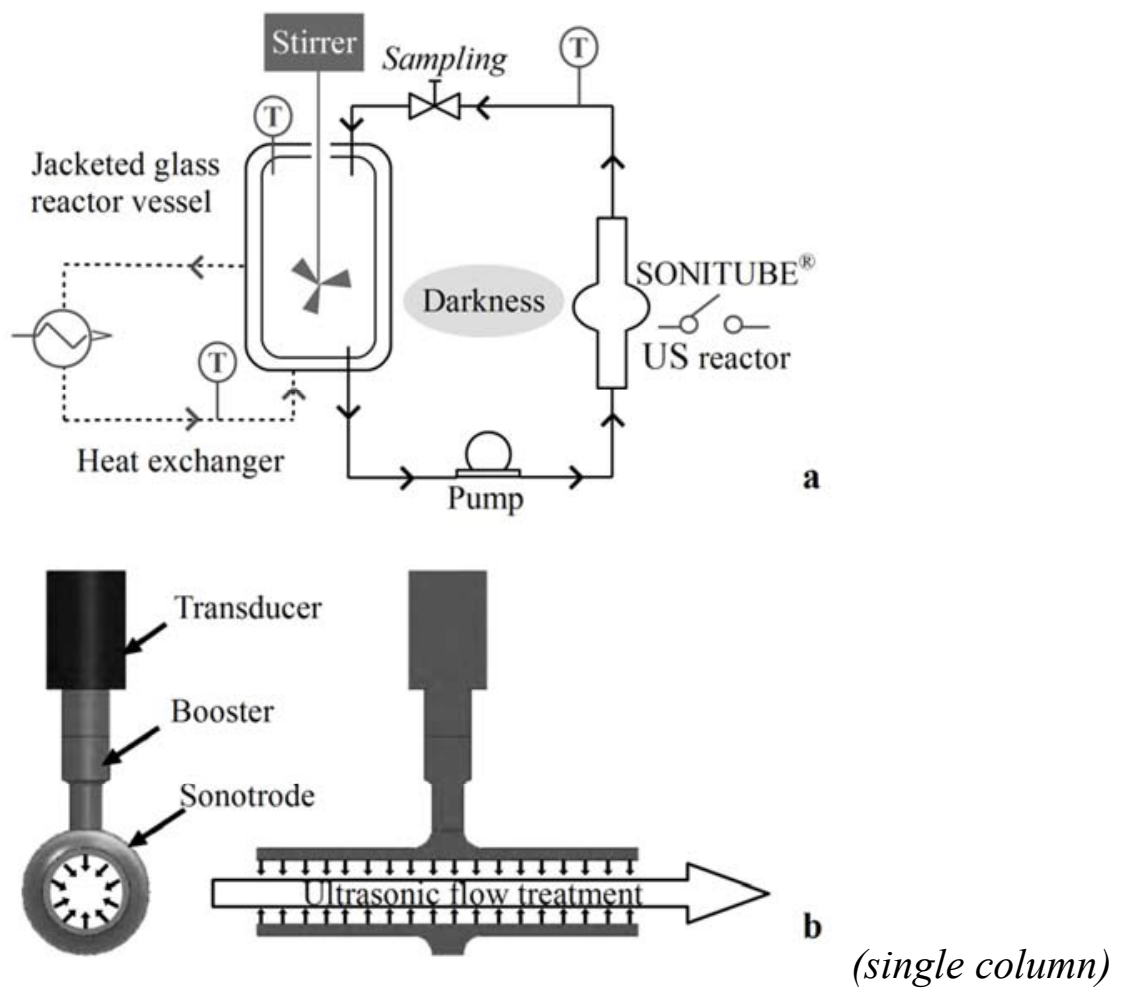

131 Figure 1. a: Diagram of the extraction system. b: Schematic illustration of the SONITUBE ${ }^{\circledR}$,

132 an ultrasonic flow-through reactor (SYNETUDE, France)

\section{2.3.1 Ultrasound-assisted extraction (UAE)}

134 The reaction mixture was sonicated for 6 hours using an ultrasonic flow-through reactor

$135\left(\mathrm{SONITUBE}^{\circledR} 35 \mathrm{kHz}, 200\right.$ to $\left.400 \mathrm{~W}\right)$, manufactured and kindly provided by SYNETUDE

136 (Chambéry, France) (Figure 1b). At the amplitude of $100 \%$, the power delivered during the

137 experiments in the reaction mixture varied between $300 \mathrm{~W}$ and $340 \mathrm{~W}$. No enzyme was added 138 during these experiments.

\section{2.3.2 Ultrasound-assisted enzymatic hydrolysis (UAEH)}

140 The UAEH process is a combination of enzymatic hydrolysis (EAE) and the UAE extraction

141 method. The UAEH was initiated by the addition of the enzymatic cocktail and the 
142 simultaneous application of US. After preliminary tests (data not shown), $1 \% \mathrm{w} / \mathrm{w}$ of each

143 enzyme related to the weight of wet seaweed was added, corresponding to a concentration of

$1440.2 \% \mathrm{w} / \mathrm{w}$ of each enzyme in the reaction mixture. Experiments were monitored during 360

$145 \min$.

$146 \quad 2.4$ Analyses

\section{2.4.1 Determination of seaweed liquefaction}

148 For all experiments, the liquefaction of the material was calculated over time. The proportion

149 of soluble material was obtained by calculating the ratio between the weight of the freeze-

150 dried supernatant $\left(m_{1}\right)$ and the weight of the freeze-dried supernatant $\left(m_{1}\right)$ added to the weight

151 of the sludge $\left(m_{2}\right)$, expressed in percentage, according to Equation (1):

152 Solubilized material $=m_{1} /\left(m_{2}+m_{1}\right) \times 100$

Eq. (1)

153 Thus, for each time, the gain in liquefaction was calculated as the proportion of soluble

154 material without the proportion of soluble material at the beginning of the process.

\section{$155 \quad$ 2.4.2 R-phycoerythrin (R-PE)}

156 Absorption spectra were monitored from 200 to $800 \mathrm{~nm}$, using a UV-VIS spectrophotometer

157 (Shimadzu UV-1800). R-PE concentrations were determined spectrometrically, using the Beer 158 and Eshel [22] equation (Equation (2)), where $A_{565}, A_{592}, A_{455}$ and $A_{492}$ are the absorbances at $159565 \mathrm{~nm}, 592 \mathrm{~nm}, 455 \mathrm{~nm}$ and $492 \mathrm{~nm}$ :

$160[\mathrm{R}-\mathrm{PE}]=\left[\left(A_{565}-A_{592}\right)-\left(A_{455}-A_{492}\right) \times 0.20\right] \times 0.12 \quad$ Eq. $(2)$

161 R-PE extraction yield was expressed as mg.g ${ }^{-1}$ seaweed dried weight (dw). 


\subsubsection{Soluble carbohydrates}

163 The water-soluble carbohydrates were analyzed using a phenol-sulfuric acid method. Glucose

164 was used as a standard (range from to 15 to $150 \mathrm{mg} . \mathrm{L}^{-1}$ ). Absorbance was measured at $490 \mathrm{~nm}$ 165 (Shimadzu UV-1800, UV-VIS Spectrophotometer) [23]. The extraction yield of soluble 166 carbohydrates was expressed as $\mathrm{mg} \cdot \mathrm{g}^{-1}$ seaweed dried weight (dw).

\subsubsection{Elemental composition: carbon and nitrogen}

168 The elemental $\mathrm{C}$ and $\mathrm{N}$ composition was determined on dehydrated samples (algal powder 169 and freeze-dried supernatants), weighed (1.5-5 mg) and placed in small tin capsules that were 170 carbonized by flash combustion at $1,800{ }^{\circ} \mathrm{C}$. The $\mathrm{C}$ and $\mathrm{N}$ contents were oxidized and 171 converted into a gaseous form, at $950{ }^{\circ} \mathrm{C}$ in a combustion column and at $750{ }^{\circ} \mathrm{C}$ in a reduction 172 column. The gases formed were transferred by carrier gas (helium) and analyzed by gas 173 chromatography (FLASH 2000 NC Organic Elemental Analyzer - Thermoscientific). The 174 results were integrated using the Eager Xperience for Flash software. Carbon and nitrogen 175 extraction yields were expressed as a percentage of the initial carbon and nitrogen seaweed 176 content $(\%)$.

\section{$177 \quad$ 2.4.5 Statistics}

178 All the extractions were carried out in three independent replicates $(n=3)$. Means and standard 179 deviations (SD) are given for three independent experiments. Analyses were performed using 180 the software Sigmastat 3.1. Multiple comparison tests were carried out using the Holm-Sidak 181 test following the ANOVA procedure $(\mathrm{p}<0.05)$. 


\section{3. Results and Discussion}

\section{$183 \quad 3.1$ R-PE temperature stability}

184 The R-PE stability according to temperature is depicted in Figure $2 \mathrm{a}$ as the percentage of 185 preserved R-PE over time.

186 Whatever the processing temperature, the level of preserved R-PE decreased with time 187 without any plateau, even after 6 hours. The shape of the curves was similar with the highest 188 denaturation occurring during the first 30 min followed by a slower one. However, a 189 temperature impact was clearly noticeable. Indeed, after $30 \mathrm{~min}$, at $4{ }^{\circ} \mathrm{C}, 94 \%$ of R-PE was 190 preserved but only $61 \%$ at $40{ }^{\circ} \mathrm{C}$ while intermediate values were found at $25{ }^{\circ} \mathrm{C}$ and $30{ }^{\circ} \mathrm{C}$ 191 (92\% and $86 \%$, respectively). After two hours, 91, 86, 76 and $35 \%$ of preserved R-PE was 192 quantified at $4,25,30$ and $40{ }^{\circ} \mathrm{C}$, respectively, while at the end of the experiments (6 hours), 193 the level of preserved R-PE was 86, 79, 63 and $26 \%$. These results clearly illustrate a 194 negative influence of temperature on the preservation of R-PE. An increase of $10{ }^{\circ} \mathrm{C}(30$ to $19540{ }^{\circ} \mathrm{C}$ ) led to a large reduction in the amount of preserved R-PE after 6 hours, from 63 to $19626 \%$.

197 A recent study demonstrated that R-PE was stable for up to $60 \mathrm{~min}$ at $40{ }^{\circ} \mathrm{C}$ while a 198 consequent denaturation occurred at $60^{\circ} \mathrm{C}[4]$. The lower stability observed here (45\% of 199 preserved R-PE after 1 hour at $40{ }^{\circ} \mathrm{C}$ ) could be due to temperature but also to $\mathrm{pH}$ as this 200 influences thermal stability [24].

201 As depicted in Figure 2b representing the absorption spectra, a noticeable effect of 202 temperature was observed after 360 min for the three main R-PE characteristic peaks (498 $203 \mathrm{~nm}, 540 \mathrm{~nm}$ and $565 \mathrm{~nm}$ ), with a regular decrease in absorbance according to the temperature 
204 increase. However, among these three, the peak at $498 \mathrm{~nm}$ demonstrated a greater stability

205 toward temperature than the 540 and $565 \mathrm{~nm}$ peaks, corresponding to the chromophores

206 phycourobilins (PUB) and phycoerythrobilins (PEB), respectively [5]. This is in accordance

207 with previous studies dealing with the thermal stability of bilins [4,25].
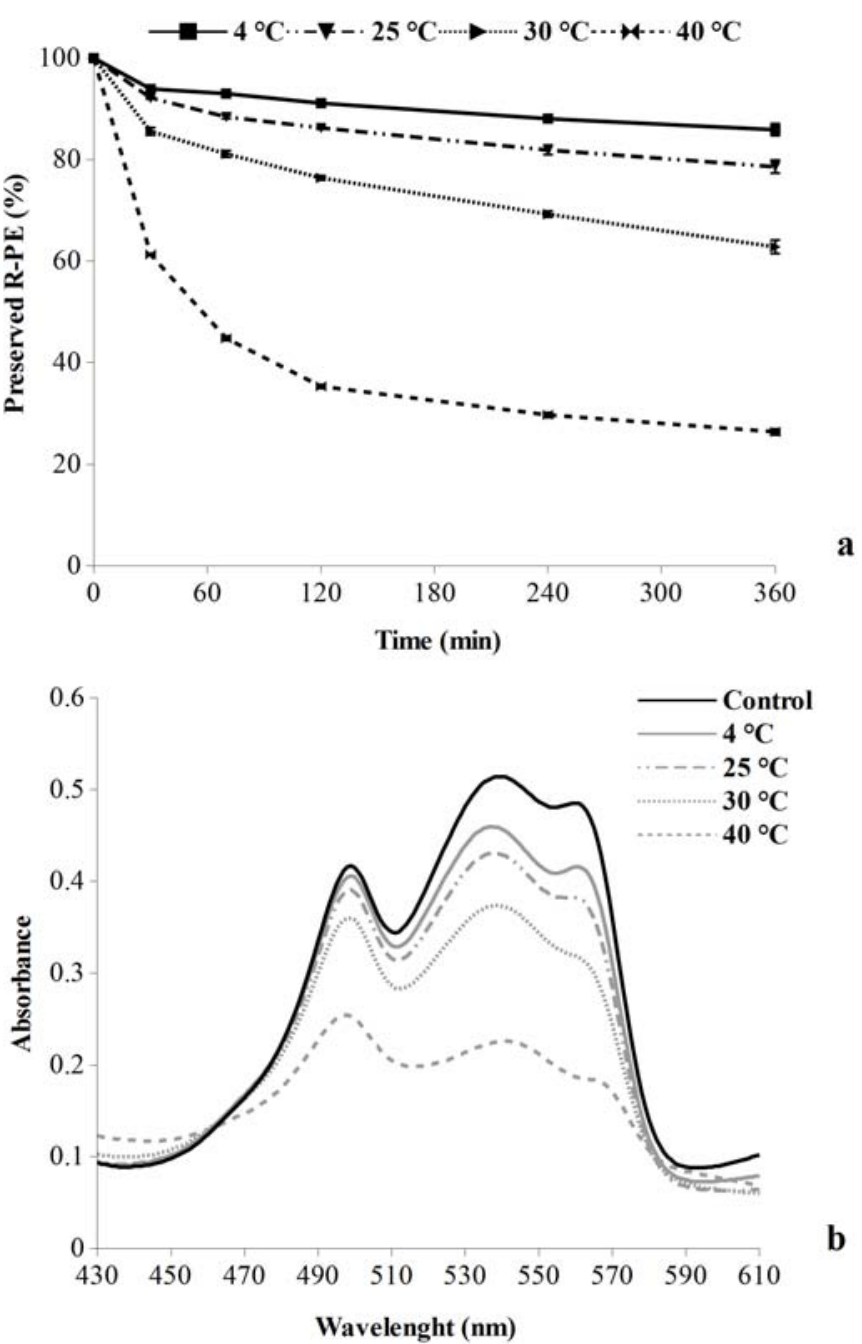

(single column)

209 Figure 2. a: Percentage of preserved R-PE over time (360 min) for the temperatures: $4{ }^{\circ} \mathrm{C}$,

$21025^{\circ} \mathrm{C}, 30{ }^{\circ} \mathrm{C}$ and $40{ }^{\circ} \mathrm{C}$. Values are means \pm SD from three independent experiments $(\mathrm{n}=3) . \mathrm{b}$ :

211 Absorption spectra of R-PE extracts after 360 min at $4{ }^{\circ} \mathrm{C}, 25^{\circ} \mathrm{C}, 30{ }^{\circ} \mathrm{C}$ and $40{ }^{\circ} \mathrm{C}$; the extract

212 at T0 was labeled Control. 


\section{3.2 Seaweed liquefaction}

214 Whatever the process or the temperature, the rate of liquefaction increased with time (Figure

215 3a), which confirms that ultrasound can reduce the hydrolysis processing time [15].

216 However, some discrepancies were found, as the gain in seaweed liquefaction over time at

217 UAEH $40{ }^{\circ} \mathrm{C}$ was much higher than that observed with other treatments. In fact, a comparison

218 of the kinetics for UAE $22{ }^{\circ} \mathrm{C}$, UAE $40{ }^{\circ} \mathrm{C}$ and UAEH $22{ }^{\circ} \mathrm{C}$ revealed that the gain in

219 liquefaction seemed to be similar over time, with the same regular and slight increase.

220 Nevertheless, when the combined process (UAEH) was applied at $40{ }^{\circ} \mathrm{C}$, the level of

221 liquefaction increased rapidly during the first 3 hours, moderately for one more hour, and was

222 then followed by a stationary phase until the end of the experiment $(40 \pm 1 \%)$.

223 After 6 hours of treatment, no statistical differences were observed for UAE processes, as the

224 final soluble contents were found identical $\left(74 \pm 4 \%\right.$ at $22{ }^{\circ} \mathrm{C}$ and $74 \pm 0.5 \%$ at $\left.40{ }^{\circ} \mathrm{C}\right)$

225 (Figure 3b). Thus, in these conditions, seaweed liquefaction by sonication was not influenced

226 by temperature. However, a recent study on grape marc demonstrated that the extraction

227 yields under sonication were correlated to temperature (from 20 to $50{ }^{\circ} \mathrm{C}$ ) but that too high

228 temperatures could have a negative effect on the ultrasonic cavitation intensity due to the

229 increase in vapor pressure [26].

230 In contrast, a clear impact of temperature was noticed when enzymes were used associated

231 with sonication (UAEH). For example, while $83.6 \pm 1.9 \%$ of solubilized material was found

232 at $22{ }^{\circ} \mathrm{C}$, up to $90.7 \pm 0.1 \%$ of soluble compounds were recovered at $40{ }^{\circ} \mathrm{C}$. This could be

233 explained by the fact that $40{ }^{\circ} \mathrm{C}$ is closer to the optimal temperature of the enzymes used, thus

234 leading to a better enzymatic efficiency. Moreover, some studies have demonstrated that the

235 activation energy (temperature) of enzymes can be lowered in the presence of ultrasound, due 
236 to their different relationship to $\mathrm{pH}$ and temperature parameters [27,28], although some

237 contradictory studies have revealed that the enzymes' optimal temperature does not change,

238 despite ultrasonic stimulation [19,29].

239 Whatever the temperature, the addition of enzymes had a positive impact on the recovery of

240 soluble materials after 6 hours of treatment $(\mathrm{p}<0.05)$. Recently, some research has been

241 carried out in order to understand how the combination of enzymes and ultrasonic waves can

242 improve extraction efficiency $[15,18,30]$. It has been demonstrated that, under sonication,

243 enzymatic activity could increase [28] due to some structural transformations (secondary

244 structure) of the active site, leading to an improved enzyme stability [19]. In contrast, it has

245 also been shown that US can reduce the specific activity of commercial enzymes, notably

246 cellulase; however, the resulting activity remained higher under sonication as the increased

247 mass transfer between enzymes and substrate could overcome this direct adverse effect on the

248 enzymes [31]. Nevertheless, it seems clear that each case is individual, depending on the type

249 of enzyme and the parameters of sonication $[31,32]$. 

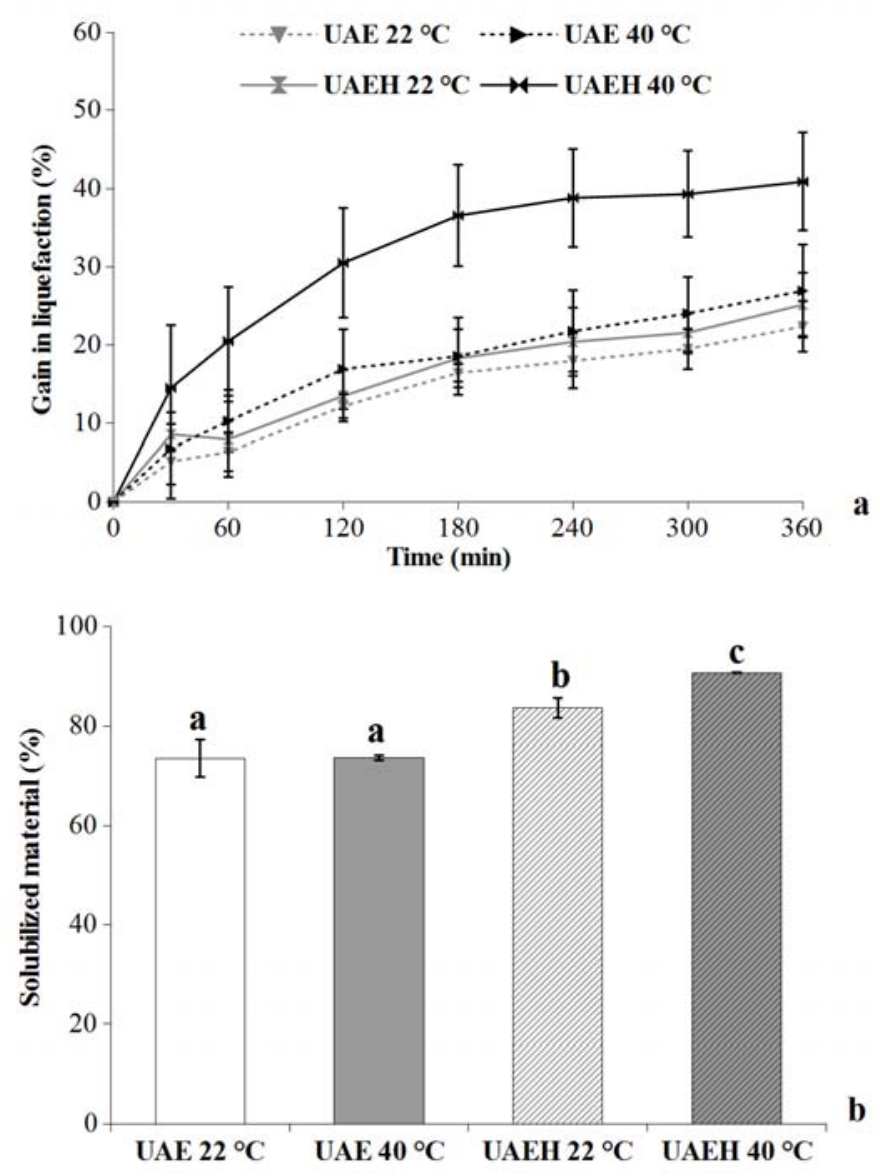

251 Figure 3. a: Evolution of the gain in seaweed liquefaction for each process (ultrasound-

252 assisted extraction (UAE) and ultrasound-assisted enzymatic hydrolysis (UAEH)) during 360

253 minutes at $40{ }^{\circ} \mathrm{C}$ and $22^{\circ} \mathrm{C}$. Values are means \pm SD from three independent experiments

$254(n=3)$. b: Percentage of solubilized material at $360 \mathrm{~min}$ for ultrasound-assisted extraction

255 (UAE) and ultrasound-assisted enzymatic hydrolysis (UAEH), at $40{ }^{\circ} \mathrm{C}$ and $22{ }^{\circ} \mathrm{C}$. Values are

256 means \pm SD from three independent experiments $(n=3)$. Significant differences $(p<0.05)$ are

257 indicated by different letters. 


\subsection{Biochemical composition of soluble fractions}

\subsubsection{R-phycoerythrin content}

260 The R-PE extraction yields measured over time are presented in Figure 4, in which some

261 kinetic differences are observed.

262 Whatever the treatment, during the first hour, two trends emerged: an increase in R-PE

263 extraction yields at $22{ }^{\circ} \mathrm{C}$ and, conversely, a decrease at $40{ }^{\circ} \mathrm{C}$. Such a reduction is consistent

264 with the denaturation previously observed at $40{ }^{\circ} \mathrm{C}(3.1)$.

265 However, after these initial 60 min, different R-PE extraction kinetics were noticed: a regular 266 reduction for $\mathrm{UAE} 22{ }^{\circ} \mathrm{C}$ and $40{ }^{\circ} \mathrm{C}$ throughout the processing time, a stagnation during one 267 more hour followed by a decrease for UAEH $22{ }^{\circ} \mathrm{C}$ and a relative stability for UAEH $40{ }^{\circ} \mathrm{C}$

$268\left(1.81 \pm 0.01 \mathrm{mg} \cdot \mathrm{g}^{-1} \mathrm{dw}\right)$. After 6 hours, UAE at $40{ }^{\circ} \mathrm{C}$ seemed to be the most denaturing 269 treatment but the final amount of preserved R-PE extracted $(39 \pm 3 \%)$ remained higher than 270 that obtained by classic tap-water extraction (26 $\pm 0.6 \%$ ) (Figure $2 a)$.

271 Regarding the extraction efficiency of R-PE from G. turuturu of the French Atlantic coast, 272 some comparisons with previous studies can be made. With the conventional extraction 273 method (in sodium phosphate buffer), yields varied between 1.2 and $4.4 \mathrm{mg} \cdot \mathrm{g}^{-1} \mathrm{dw}[2,6]$. 274 However, according to Figure 4, after 2 hours of extraction at $22{ }^{\circ} \mathrm{C}$ with UAEH or UAE, they 275 reached $3.6 \pm 0.3 \mathrm{mg} \cdot \mathrm{g}^{-1}$ and $3.1 \pm 0.1 \mathrm{mg} \cdot \mathrm{g}^{-1} \mathrm{dw}$, respectively, which is in the range of the 276 conventional solid-liquid extraction.

277 Whatever the temperature, the addition of enzymes always led to higher extraction rates 278 ( $\mathrm{p}<0.05)$. At the end of the processes $(360 \mathrm{~min})$, no significant differences were noticed 279 between UAE $22{ }^{\circ} \mathrm{C}$ and UAEH $22{ }^{\circ} \mathrm{C}$ while at $40{ }^{\circ} \mathrm{C}$, the R-PE yield with UAEH was higher 
280 than with UAE, which could be associated with the positive action of enzymes at $40{ }^{\circ} \mathrm{C}$, as

281 previously mentioned.

282 Nevertheless, $22{ }^{\circ} \mathrm{C}$ is preferable as at this temperature, the thermal denaturation of R-PE is

283 limited. This is in accordance with a previous study on the red seaweed Palmaria palmata,

284 which demonstrated that the extraction of R-PE, by enzymatic hydrolysis, was improved by

285 reducing the temperature to $25^{\circ} \mathrm{C}$ [7].

286 Based on these results, some assumptions can be formulated: 1- R-PE would be more stable

287 toward temperature in our soluble phase than in a tap-water extract due to the presence of

288 other co-extracted compounds, such as polysaccharides or oligosaccharides (see below, Figure

289 5a); 2- the extraction yield of R-PE was the difference between extraction and denaturation

290 over time; 3- soluble R-PE could be more sensitive to sonication than non-extracted R-PE,

291 leading to its denaturation over time. Indeed, a recent study on the UAE of water-soluble

292 pigments from Bougainvillea glabra flowers found that temperature was more influential than

293 cavitation on the extraction of pigments, as they are temperature-sensitive [33]. Thus,

294 temperature could have both positive and negative effects: it increased the solubility of solids

295 (including pigments) from the biomass (Figure 3b) but, beyond a certain temperature,

296 ultrasonic cavitation could be altered and pigments damaged by thermal denaturation.

297 In accordance with our assumption 3, it is possible that too long an exposure of pigments to

298 ultrasonic waves, even at $22{ }^{\circ} \mathrm{C}$, induced their structural destruction leading to a lower yield

299 [33]. For example, at $22{ }^{\circ} \mathrm{C}$, the extension of the UAEH treatment from one to six hours led to

300 the denaturation of $31 \%$ of extracted R-PE.

301 It is important to keep in mind that sensitivity toward temperature and ultrasonic waves,

302 depends on the type of molecules and the experimental parameters. As previously mentioned 
303 by Roselló-Soto et al. [34], the UAE technique should be carefully used in the extraction of

304 unstable compounds (like carotenoids and chlorophylls) and the conditions optimized

305 accordingly.

306 In this study, one or two hours of ultrasonic treatment of G. turuturu with or without enzymes

307 at $22{ }^{\circ} \mathrm{C}$ appeared the most efficient to extract R-PE like the classic procedure. Furthermore,

308 with this new process, the steps of freeze-drying and grinding in liquid nitrogen were avoided,

309 saving time and energy. To an economical and trans positional point of view, and according to

310 the ultrasonic reactor used there, such process could be used with volume up to $50 \mathrm{~L}$

311 moreover it could be upscaled to up to 200 or $300 \mathrm{~L}$ while with using the same technology

312 and powered by a SONITUBE ${ }^{\circledR} 20 \mathrm{kHz}$. As mentioned in the study of Denis et al. [35], a

313 membrane process dealing with the recovery of around 30 L.day $^{-1}$ with a cost of $1 € . \mathrm{L}^{-1}$ of pre

314 purified fraction of $0.245 \mathrm{~g}$ of R-PE.L ${ }^{-1}$. Here, with a $3 \mathrm{~L}$ reaction mixture it's up to $0.306 \mathrm{~g}$ of

315 R-PE that could be extracted thus equivalent to $0.102 \mathrm{~g}$ of R-PE.L $\mathrm{L}^{-1}$ without any purification.

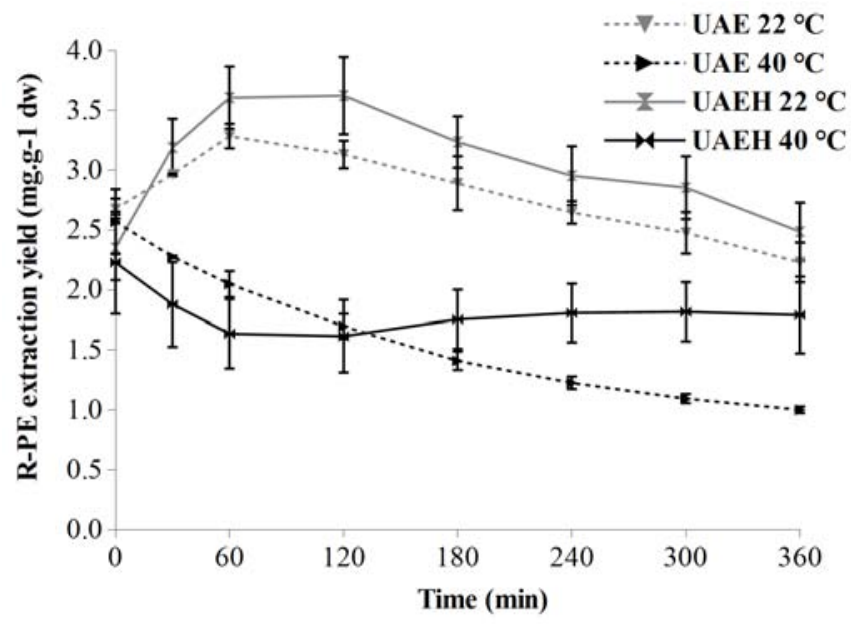

(1.5 column $)$

317 Figure 4. Evolution of the R-PE extraction yield for each process (ultrasound-assisted

318 extraction (UAE) and ultrasound-assisted enzymatic hydrolysis (UAEH)) during 360 minutes

319 at $40{ }^{\circ} \mathrm{C}$ and $22{ }^{\circ} \mathrm{C}$. Values are means \pm SD from three independent experiments $(n=3)$. 
321 In order to qualify the dry matter content, some biochemical analyses were carried out on the

322 resulting soluble fractions. To ensure the accuracy of our values, enzymatic cocktail

323 carbohydrates were estimated at $427.43 \mathrm{mg}$ of carbohydrate per $\mathrm{g}$ of enzymatic cocktail. This

324 is in accordance with data provided by the suppliers as: Sumizyme TG contains $50 \%$

325 dextrins, Sumizyme MC is composed of $79 \%$ maltodextrins and Ultraflo ${ }^{\circledR}$ XL by $30 \%$

326 glycerol and $20 \%$ sorbitol. No data were communicated for Multifect ${ }^{\circledR}$ CX 15L. In order to

327 avoid an overestimation, these amounts were compared to dried seaweed, giving an overall

328 value of $127.41 \mathrm{mg}$ of carbohydrate per $\mathrm{g}$ of dried seaweed. This was removed from the

329 biochemical composition of soluble fractions for UAEH processes. The biochemical

330 compositions of the resulting fractions obtained after 6 hours of treatment are presented in

331 Figure 5.

332 The comparison of soluble carbohydrates extracted by sonication (UAE) and ultrasound-

333 assisted enzymatic hydrolysis (UAEH) demonstrated that the temperature did not affect

334 significantly the extraction of carbohydrates by sonication alone (Figure 5a). However, at

$33540{ }^{\circ} \mathrm{C}$, the combined process (UAEH) increased significantly the carbohydrate release (439 \pm

$\left.33616 \mathrm{mg} \cdot \mathrm{g}^{-1} \mathrm{dw}\right)$ compared to sonication alone $\left(296 \pm 37 \mathrm{mg} \cdot \mathrm{g}^{-1} \mathrm{dw}\right)$.

337 Thus, as previously noticed, the simultaneous combination of ultrasound and enzymes may

338 have improved the process efficiency, leading to higher levels of polysaccharide extraction

339 and hydrolysis (fermentable sugars) $[15,16,18,30]$. In our conditions, an increase in the

340 temperature for the UAEH process significantly enhanced the extraction of soluble

341 carbohydrates from 210 to $439 \mathrm{mg} \cdot \mathrm{g}^{-1} \mathrm{dw}$, which is in accordance with previous work [17]. A

342 relationship can be made between the extraction of carbohydrates and the results of the R-PE 
343 extraction yield (Figure 4). For example, as mentioned in assumption 1 (3.3.1), it is possible

344 that soluble carbohydrates contribute to R-PE preservation, as it seems that the presence of

345 uncharged glucan could prevent the thermal degradation of R-PE [25]. At least some side

346 effects of the released polysaccharides, such as antioxidant properties, could also contribute to

347 this preservation $[17,36]$.

348 Regarding carbon and nitrogen, whatever the temperature, they were better extracted by

349 UAEH treatments compared to UAE ones (Figure 5b and c). However, a positive temperature

350 effect was only noticeable for carbon with UAEH as $83 \%$ of the initial carbon was extracted

351 at $22{ }^{\circ} \mathrm{C}$ and $92 \%$ at $40{ }^{\circ} \mathrm{C}$. For nitrogen, no statistical differences were observed between

$352 \mathrm{UAEH}$ at $22{ }^{\circ} \mathrm{C}$ and $40{ }^{\circ} \mathrm{C}$ (Figure 5c).

353 All these results clearly demonstrate an enzymatic effect as the polysaccharidases, with an

354 optimal temperature close to $40{ }^{\circ} \mathrm{C}$ (Table 1), improved the extraction of carbohydrates and

355 carbon components at $40{ }^{\circ} \mathrm{C}$ rather than nitrogen components. Differences between

356 carbohydrates and carbon, for UAEH $22{ }^{\circ} \mathrm{C}$, could be explained by the presence of carbon in

357 both proteins and carbohydrates. 

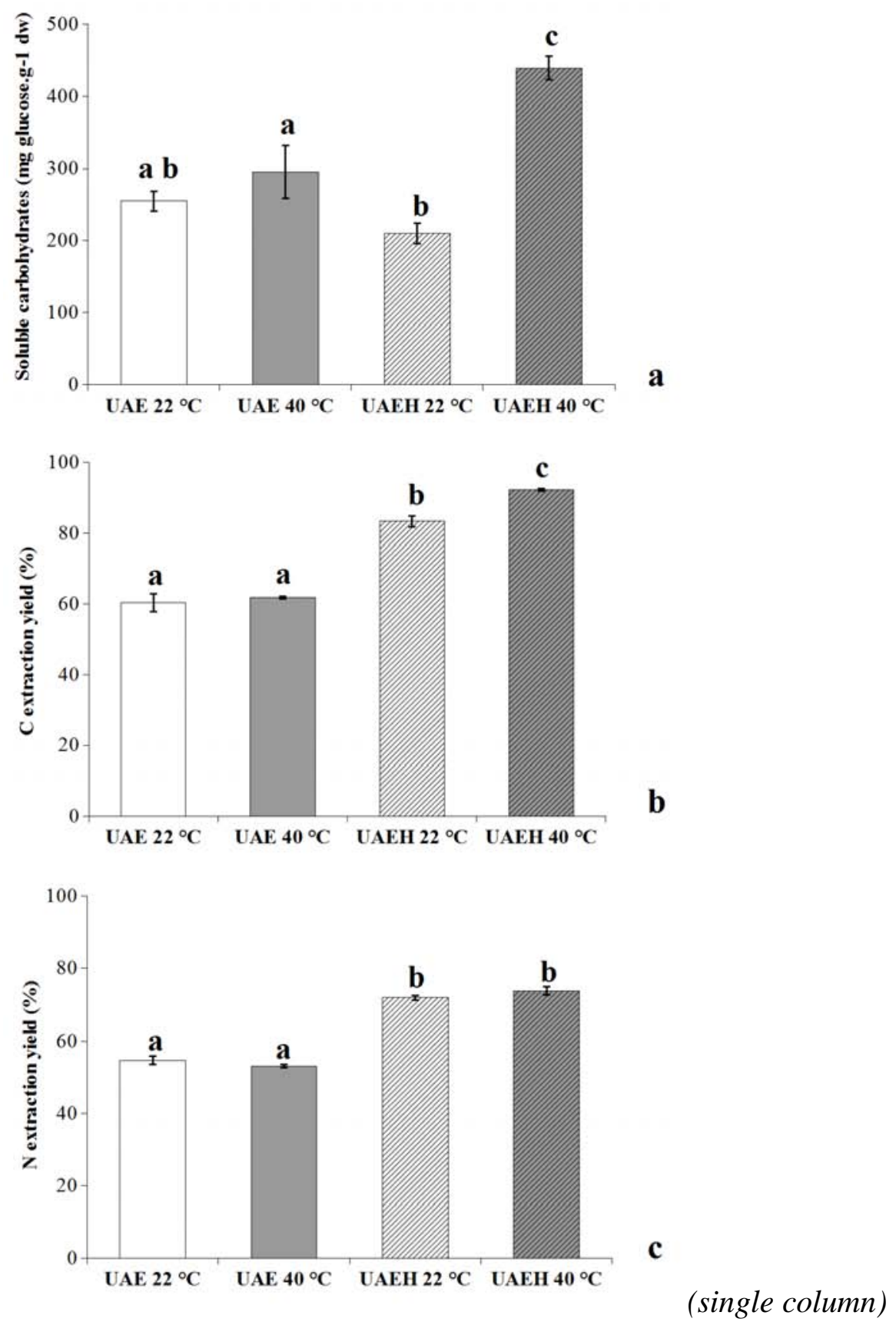

359 Figure 5. Biochemical composition of soluble fractions at $360 \mathrm{~min}$ for ultrasound-assisted 360 extraction (UAE) and ultrasound-assisted enzymatic hydrolysis (UAEH) at $40{ }^{\circ} \mathrm{C}$ and $22{ }^{\circ} \mathrm{C}$.

361 a: Carbohydrates, b: Carbon and c: Nitrogen. Values are means \pm SD from three independent

362 experiments $(n=3)$. Significant differences $(\mathrm{p}<0.05)$ are indicated by different letters. 


\section{4. Conclusions}

364 These results highlight some differences between R-PE extraction and seaweed liquefaction.

365 For liquefaction, the UAEH process at $40{ }^{\circ} \mathrm{C}$ for 6 hours (at least 4 hours) appeared to be the

366 best condition with up to $91 \%$ of solubilized material. For R-PE, both UAE and UAEH at

$36722{ }^{\circ} \mathrm{C}(60-120 \mathrm{~min})$ were suitable, with extraction yields (around $3.6 \mathrm{mg} \cdot \mathrm{g}^{-1} \mathrm{dw}$ for UAEH)

368 close to conventional solid-liquid extraction. However, UAEH $22{ }^{\circ} \mathrm{C}$ also demonstrated a

369 greater extraction of other water-soluble compounds. Thus, further work is needed in order to

370 find the best compromise for R-PE extraction and Grateloupia turuturu liquefaction. 


\section{Acknowledgements}

372 This research was supported by the Région Pays de La Loire and the MSH Ange Guépin,

373 France (COSELMAR project). We thank DSM, Novozymes ${ }^{\circledR}$ and Takabio for kindly

374 providing the enzymes, SYNETUDE for providing the SONITUBE ${ }^{\circledR}$ and Carol Robins for

375 her expertise in scientific English. The authors thank Marion Liennard and Andrea Villa

376 López for their active involvement in this study, and Ewa Lukomska for elemental analyses. 


\section{References}

378 [1] R.S. Baghel, N. Trivedi, V. Gupta, A. Neori, C.R.K. Reddy, A. Lali, et al., Biorefining of marine macroalgal biomass for production of biofuel and commodity chemicals, Green Chem. 17 (2015) 2436 -2443. doi:10.1039/C4GC02532F.

[2] M. Munier, J. Dumay, M. Morançais, P. Jaouen, J. Fleurence, Variation in the Biochemical Composition of the Edible Seaweed Grateloupia turuturu Yamada Harvested from Two Sampling Sites on the Brittany Coast (France): The Influence of Storage Method on the Extraction of the Seaweed Pigment R-Phycoerythrin, J. Chem. 2013 (2013) 1-8. doi:10.1155/2013/568548.

[3] J. Dumay, M. Morançais, M. Munier, C. Le Guillard, J. Fleurence, Chapter Eleven Phycoerythrins: Valuable Proteinic Pigments in Red Seaweeds, in: N. Bourgougnon (Ed.), Advances in Botanical Research, Sea Plants, Academic Press, 2014, pp. 321-343.

[4] M. Munier, S. Jubeau, A. Wijaya, M. Morançais, J. Dumay, L. Marchal, et al., Physicochemical factors affecting the stability of two pigments: R-phycoerythrin of Grateloupia turuturu and B-phycoerythrin of Porphyridium cruentum, Food Chem. 150 (2014) 400-407. doi:10.1016/j.foodchem.2013.10.113. 
400 [6] C. Denis, M. Morançais, M. Li, E. Deniaud, P. Gaudin, G. Wielgosz-Collin, et al., Study of the 401 chemical composition of edible red macroalgae Grateloupia turuturu from Brittany (France), $402 \quad$ Food Chem. 119 (2010) 913-917. doi:10.1016/j.foodchem.2009.07.047.

403

404 [7] J. Dumay, N. Clément, M. Morançais, J. Fleurence, Optimization of hydrolysis conditions of Palmaria palmata to enhance R-phycoerythrin extraction, Bioresour. Technol. 131 (2013) 2127. doi:10.1016/j.biortech.2012.12.146.

407

[8] W.A.J.P. Wijesinghe, Y.-J. Jeon, Enzyme-assistant extraction (EAE) of bioactive components: A useful approach for recovery of industrially important metabolites from seaweeds: A review, Fitoterapia. 83 (2012) 6-12. doi:10.1016/j.fitote.2011.10.016.

412 [9] C. Denis, M. Morançais, P. Gaudin, J. Fleurence, Effect of enzymatic digestion on thallus 413 degradation and extraction of hydrosoluble compounds from Grateloupia turuturu, Bot. Mar. 52 (2009) 262-267. doi:10.1515/BOT.2009.035.

416 [10] T.J. Mason, F. Chemat, M. Vinatoru, The Extraction of Natural Products using Ultrasound or Microwaves, Curr. Org. Chem. 15 (2011) 237-247. doi:10.2174/138527211793979871.

419 [11] S.U. Kadam, B.K. Tiwari, C.P. O’Donnell, Application of novel extraction technologies for 420 bioactives from marine algae, J. Agric. Food Chem. 61 (2013) 4667-4675. doi:10.1021/jf400819p. 
423 [12] S.U. Kadam, B.K. Tiwari, T.J. Smyth, C.P. O’Donnell, Optimization of ultrasound assisted 424 extraction of bioactive components from brown seaweed Ascophyllum nodosum using 425 response surface methodology, Ultrason. Sonochem. 23 (2015) 308-316.

426 doi:10.1016/j.ultsonch.2014.10.007.

428 [13] F. Wang, X.-Y. Guo, D.-N. Zhang, Y. Wu, T. Wu, Z.-G. Chen, Ultrasound-assisted extraction and purification of taurine from the red algae Porphyra yezoensis, Ultrason. Sonochem. 24 (2015) 36-42. doi:10.1016/j.ultsonch.2014.12.009.

[14] J. Benavides, M. Rito-Palomares, Simplified two-stage method to B-phycoerythrin recovery from Porphyridium cruentum, J. Chromatogr. B. 844 (2006) 39-44. doi:10.1016/j.jchromb.2006.06.029.

[15] Y. Liu, G. Gong, J. Zhang, S. Jia, F. Li, Y. Wang, et al., Response surface optimization of ultrasound-assisted enzymatic extraction polysaccharides from Lycium barbarum, Carbohydr. Polym. 110 (2014) 278-284. doi:10.1016/j.carbpol.2014.03.040.

[16] F.C. Lunelli, P. Sfalcin, M. Souza, E. Zimmermann, V. Dal Prá, E.L. Foletto, et al.,

[17] H. Wu, J. Zhu, W. Diao, C. Wang, Ultrasound-assisted enzymatic extraction and antioxidant activity of polysaccharides from pumpkin (Cucurbita moschata), Carbohydr. Polym. 113 
449 [18] V. Yachmenev, B. Condon, T. Klasson, A. Lambert, Acceleration of the Enzymatic Hydrolysis 450 of Corn Stover and Sugar Cane Bagasse Celluloses by Low Intensity Uniform Ultrasound, J. 451 Biobased Mater. Bioenergy. 3 (2009) 25-31. doi:10.1166/jbmb.2009.1002.

453 [19] M. Bashari, A. Eibaid, J. Wang, Y. Tian, X. Xu, Z. Jin, Influence of low ultrasound intensity on 454 the degradation of dextran catalyzed by dextranase, Ultrason. Sonochem. 20 (2013) 155-161. doi:10.1016/j.ultsonch.2012.06.010.

[20] C. Peña-Farfal, A. Moreda-Piñeiro, A. Bermejo-Barrera, P. Bermejo-Barrera, H. PinochetCancino, I. de Gregori-Henríquez, Speeding up enzymatic hydrolysis procedures for the multielement determination in edible seaweed, Anal. Chim. Acta. 548 (2005) 183-191.

461 doi:10.1016/j.aca.2005.06.004.

[22] S. Beer, A. Eshel, Determining Phycoerythrin and Phycocyanin Concentration in Aqueous

[21] L. Korzen, I.N. Pulidindi, A. Israel, A. Abelson, A. Gedanken, Single step production of bioethanol from the seaweed Ulva rigida using sonication, RSC Adv. 5 (2015) 16223-16229. doi:10.1039/C4RA14880K. 
469 [23] M.F. Chaplin, Monosaccharides, in: Chaplin M.F., J.F. Kennedy (Eds.), Carbohydrate analysis: a practical approach, First, IRL Press, Oxford, 1986, pp. 1-36.

471

472 [24] A. Orta-Ramirez, J. E. Merrill, D. M. Smith, pH Affects the Thermal Inactivation Parameters of R-Phycoerythrin from Porphyra yezoensis, J. Food Sci. 65 (2000) 1046-1050. doi:10.1111/j.1365-2621.2000.tb09415.x.

[25] E. D'Agnolo, E. Murano, R. Rizzo, S. Paoletti , A biliprotein from the red alga Gracilaria longa: thermal stability of R-Phycoerythrin, Ital. J. Biochem. 42 (1993) 316A-318A.

[26] Y. Tao, Z. Zhang, D.-W. Sun, Kinetic modeling of ultrasound-assisted extraction of phenolic compounds from grape marc: Influence of acoustic energy density and temperature, Ultrason. Sonochem. 21 (2014) 1461-1469. doi:10.1016/j.ultsonch.2014.01.029.

[27] E.X. Leaes, D. Lima, L. Miklasevicius, A.P. Ramon, V. Dal Prá, M.M. Bassaco, et al., Effect of ultrasound-assisted irradiation on the activities of $\alpha$-amylase and amyloglucosidase, Biocatal. Agric. Biotechnol. 2 (2013) 21-25. doi:10.1016/j.bcab.2012.08.003.

[28] M. Souza, E.T. Mezadri, E. Zimmerman, E.X. Leaes, M.M. Bassaco, V. Dal Prá, et al., Evaluation of activity of a commercial amylase under ultrasound-assisted irradiation, Ultrason. Sonochem. 20 (2013) 89-94. doi:10.1016/j.ultsonch.2012.05.012. 
491

492

493

494

495

496

497

498

499

500

501

502

503

504

505

506

507

508

509

510

511

512

513

[29] J. Wang, Y. Cao, B. Sun, C. Wang, Y. Mo, Effect of ultrasound on the activity of alliinase from fresh garlic, Ultrason. Sonochem. 18 (2011) 534-540. doi:10.1016/j.ultsonch.2010.09.008.

[30] E.X. Leaes, E. Zimmermann, M. Souza, A.P. Ramon, E.T. Mezadri, V. Dal Prá, et al., Ultrasound-assisted enzymatic hydrolysis of cassava waste to obtain fermentable sugars, Biosyst. Eng. 115 (2013) 1-6. doi:10.1016/j.biosystemseng.2013.02.001.

[31] O.E. Szabó, E. Csiszár, The effect of low-frequency ultrasound on the activity and efficiency of a commercial cellulase enzyme, Carbohydr. Polym. 98 (2013) 1483-1489. doi:10.1016/j.carbpol.2013.08.017.

[32] B. Özbek, K.Ö. Ülgen, The stability of enzymes after sonication, Process Biochem. 35 (2000) 1037-1043. doi:10.1016/S0032-9592(00)00141-2.

[33] J.P. Maran, B. Priya, C.V. Nivetha, Optimization of ultrasound-assisted extraction of natural pigments from Bougainvillea glabra flowers, Ind. Crops Prod. 63 (2015) 182-189. doi:10.1016/j.indcrop.2014.09.059.

[34] E. Roselló-Soto, C.M. Galanakis, M. Brnčić, V. Orlien, F.J. Trujillo, R. Mawson, et al., Clean recovery of antioxidant compounds from plant foods, by-products and algae assisted by ultrasounds processing. Modeling approaches to optimize processing conditions, Trends Food Sci. Technol. 42 (2015) 134-149. doi:10.1016/j.tifs.2015.01.002. 
514 [35] C. Denis, A. Massé, J. Fleurence, P. Jaouen, Concentration and pre-purification with

515 ultrafiltration of a R-phycoerythrin solution extracted from macro-algae Grateloupia turuturu:

$516 \quad$ Process definition and up-scaling, Sep. Purif. Technol. 69 (2009) 37-42.

517 doi:10.1016/j.seppur.2009.06.017.

518

519 [36] C. Zhou, X. Yu, Y. Zhang, R. He, H. Ma, Ultrasonic degradation, purification and analysis of 520 structure and antioxidant activity of polysaccharide from Porphyra yezoensis Udea,

$521 \quad$ Carbohydr. Polym. 87 (2012) 2046-2051. doi:10.1016/j.carbpol.2011.10.026. 